\title{
Intragastric Migration of Gastric Band Diagnosed During Surgery: A Case Report and Literature
}

\section{Cerrahi Sırasında Tanı Konulan Gastrik Bandın Intragastrik Migrasyonu: Olgu Sunumu ve Literatür Incelemesi}

\author{
๑ Mehmet Uluşahin, ๑ Reyyan Yıldırım, • Kadir Tomas, • Muhammed Selim Bodur, \\ ๑ Serkan Tayar, ๑ Serdar Türkyılmaz, ๑ Ali Güner
}

Karadeniz Technical University, Farabi Hospital, Clinic of General Surgery, Trabzon, Türkiye

\begin{abstract}
Intragastric band migration (IGBM) is one of the major complications of gastric banding. In this report, we aimed to present a case of IGBM, which was diagnosed intraoperatively, and to review the relevant literature. A 59-year-old male patient was admitted to our outpatient clinic due to epigastric pain persisting for the past three months. The patient had a history of gastric banding surgery owing to obesity with open surgery nine years ago. Postoperative follow-up was not done properly and the patient had started to gain weight in the third postoperative year. Incisional hernia was found in physical examination and operation for gastric band removal and hernia repair was planned. During surgery, the band could not be found around the stomach, therefore, gastroscopy was performed and it was found that the majority of the band was placed in the stomach. The patient was intraoperatively diagnosed with IGBM and the band was removed through gastrotomy, and hernia repair was performed. The patient was discharged at postoperative $6^{\text {th }}$ day without any complication. Although IGBM is rarely seen, it should be considered as a long-term complication in cases with dysfunctional gastric band and in patients who started to gain weight after operation. Treatment is the removal of the band review.
\end{abstract}

Keywords: Intragastric band migration, bariatric surgery, complication, obesity surgery
Intragastrik band migrasyonu (IGBM) gastrik band yerleştirilmesinin nadir gözüken majör komplikasyonlarından biridir. Bu yazıda intraoperatif tanı koyulan IGBM olgusunu sunmayı ve IGBM konusundaki literatürü derlemeyi amaçladık. Elli dokuz yaşında erkek hasta üç aydır olan epigastrik ağıı nedeni ile polikliniğimize başvurdu. Öyküsünde obezite nedeni ile dokuz yıl önce açık yöntemle gastrik band uygulandığı öğrenildi. Operasyon sonrası takipleri düzgün yapılmamıştı ve postoperatif üçüncü yıldan sonra tekrar kilo almaya başladı. Fizik muayenesinde insizyonel hernisi olan hastaya gastrik bandın çıkartılması ve herni tamiri nedeni ile operasyon planlandı. Operasyon sırasında band mide etrafında bulunamayınca intraoperatif gastroskopi yapıldı ve bandın büyük bir kısmının mide içinde olduğu tespit edildi. Hastaya operasyon sırasında IGBM tanısı konuldu ve band gastrotomi ile çıkartıldı, herni tamiri yapıldı. Postoperatif takiplerinde problem olmayan hasta altıncı günde taburcu edildi. IGBM nadir gözükmesine rağmen işlev görmeyen gastrik band durumlarında ve kilo almaya tekrar başlayan hasta gruplarında uzun dönem komplikasyon olarak akılda bulundurulmalıdır. Tedavisi bandın çıkartılmasıdır.

Anahtar Sözcükler: İntragastrik band migrasyonu, bariatrik cerrahi, komplikasyon, obezite cerrahisi

\section{Introduction}

Surgical treatment of obesity has become quite common during the last decade and it has been increasingly performed. Different surgical techniques have been used for treating obesity in years. Among these techniques, adjustable gastric banding (AGB) has been frequently used due to its easy applicability and relatively low complication rates (1). Although intragastric band migration (IGBM) 
among the complications of this technique is rarely seen, it is a complication which may cause serious consequences $(2,3)$.

In this study, we aimed to present a case of IGBM identified during operation in a patient who underwent dysfunctional gastric band removal and to review the literature.

\section{Case}

A 59-year-old male patient was admitted to the general surgery outpatient clinic at our hospital with epigastric pain persisted for the past three months. In anamnesis, it was found that he had undergone open gastric banding due to obesity with a body mass index (BMI) of 49.2 about nine years ago and also underwent re-operation due to early preoperative distal band slippage for fixation of the band to the stomach. During following years, the patient's BMI had decreased to 34, however, he had started gaining weight and the patient dropped out of his follow-ups. The patient was $120 \mathrm{~kg}$ and his BMI was 42.9 on admission. An incisional hernia arising from the supraumblical median incision healed with a bad scar tissue was present and the area around the port was hyperemic. The patient stated that this area had frequently become hyperemic and hyperemia resolved after antibiotic therapy. An operation for incisional hernia repair and removal of the dysfunctional gastric band was planned. The patient did not require another bariatric procedure. Endoscopic examination of the upper gastrointestinal system (GIS) was not performed in his previous follow-up period.

During the operation performed through supraumblical incision under general anesthesia, a connector providing connection between gastric band and port was followed for reaching the band around the stomach, however, the band could not be seen around the stomach.

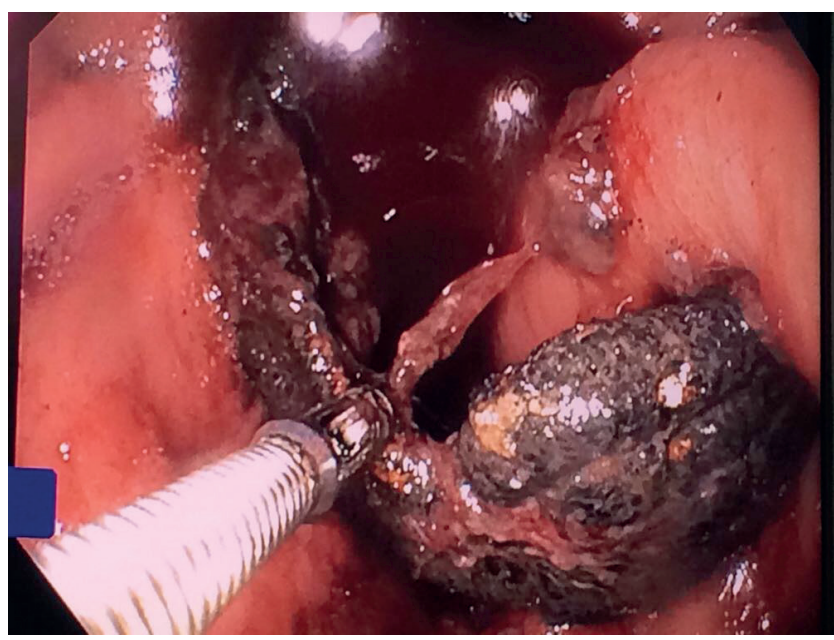

Figure 1. Intraoperative endoscopic view of intragastric migration of gastric band
Considering the possibility of IGBM, intraoperative upper GIS endoscopy was performed and the gastric band was found as mostly placed in the stomach; especially on the proximal stomach (Figure). Then, the entrance point of the band to the stomach was identified by following the connector. Gastrotomy was performed on this area on the lesser curvature at proximal stomach; and band was cut and excised. Gastrotomy was closed with sutures. There was no other perforation or fistula origin in the stomach. Additionally, hernia repair was performed with primary sutures. The patient was discharged at postoperative $6^{\text {th }}$ day without any complication. There was also no problem in follow-ups after discharge; and BMI and weight of the patient were recorded at postoperative $18^{\text {th }}$ month as 42.9 and $126 \mathrm{~kg}$, respectively. Informed consent was obtained from the patient for all treatment process and also for the publishing of the results.

IGBM prevalence and diagnosis/treatment approaches in different series in the literature are summarized in Table. The rate of complication associated with laparoscopic AGB (LAGB) and IGBM have been reported to be $8-50.4 \%$ and $0.24-2.85 \%$, respectively. Pars flaccida was the most common technique and laparoscopy was most commonly chosen approach as treatment modality. In addition, cases treated with excision through open surgery have also been reported.

\section{Discussion}

Surgical treatment methods for weight loss by restricting calorie intake or reducing absorption or combination of both of them are named bariatric surgery. Although it was first performed during 1950s; it has gained popularity in the last two decades. In spite of differences between the chosen methods in time; LAGB, Roux-en-Y gastric bypass, and sleeve gastrectomy have been the most frequently performed methods. Although LAGB method has lower success rate in weight loss when compared with other techniques, it has been a preferred technique due to low complication rates and lower risks of malnutrition and vitamin deficiency. It was defined as a safe method, however, different complications, such as gastric perforation, gastrogastric fistula, band slippage, pouch dilatation, esophageal dilatation, gastric volvulus, and IGBM, associated with gastric banding have been reported (6). In this paper, we presented a case of IGBM occurred late after gastric banding and aimed to evaluate different diagnostic and treatment approaches towards IGBM reported in the literature.

The incidence of IGBM has been reported to be lower than $1 \%$ in centers specified in obesity surgery with high patient volume; and as high as $10-20 \%$ in centers at the 
Uluşahin et al. Intragastric Migration of Gastric Band

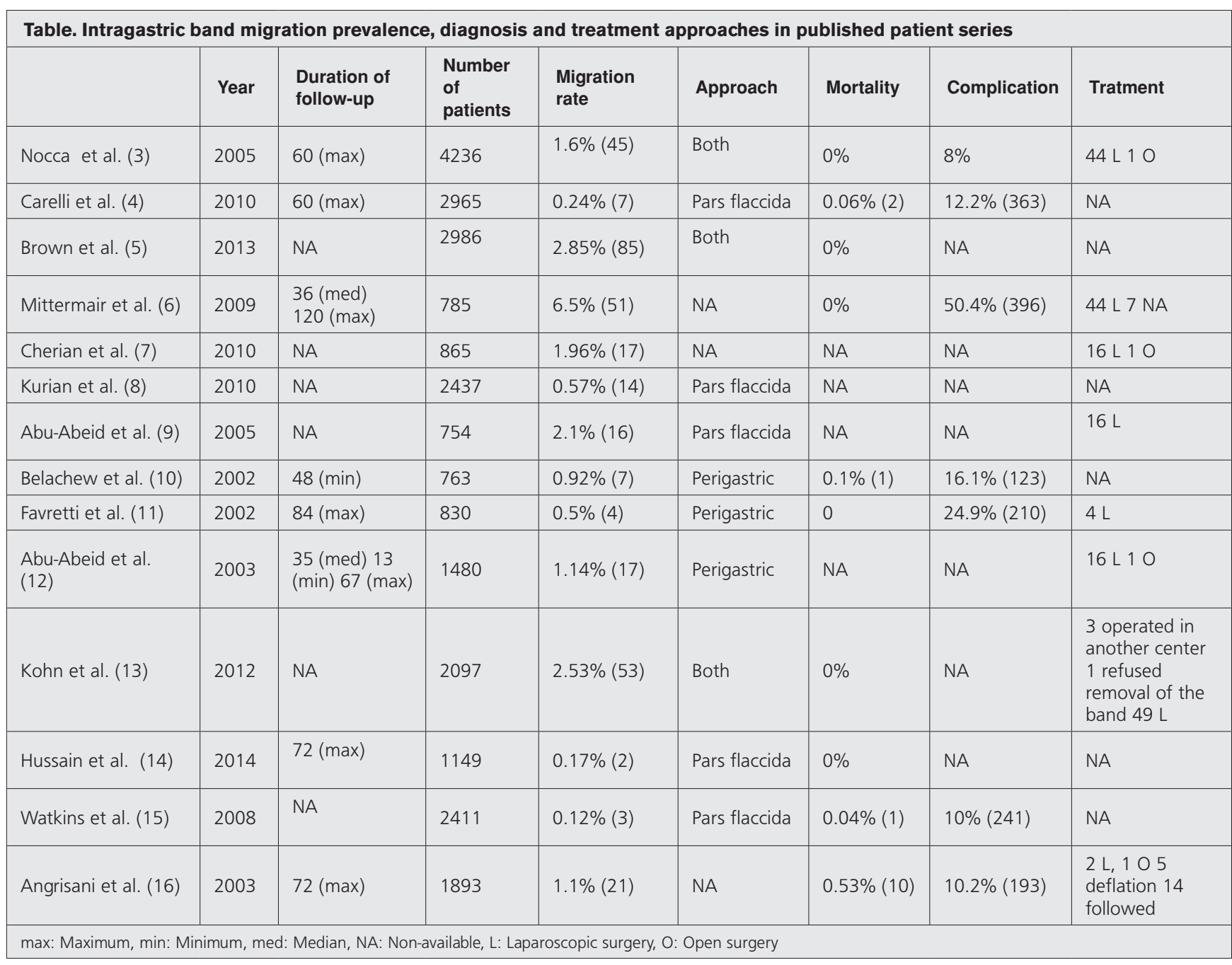

start of learning curve $(1,3,4,17)$. In addition, migration incidence is higher during the first two years of surgeon's practice in a technique $(5,7,18)$. It is remarkable that rates of IGBM occurrence and experience of the surgeon are associated parameters when the rates in centers with high patient volume and experience were evaluated.

Epigastric pain, weight gain and port infection are the most common symptoms observed in patients with $\operatorname{IGBM}(7,19)$. Feeling of hunger, lack of satiety, nonspecific abdominal pain, dysphagia, and rarely peritonitis and abscess are other symptoms, however, patients may present without any clinical findings or with fatal and unexpected clinical conditions such as hematemesis $(18,20)$. Time of IGBM occurrence may range between postoperative $3^{\text {rd }}$ month and postoperative years. In our case, inflammation which had intermittently occurred around the port area and responded to antibiotics and the complaint of weight gain started three years after the first operation. The complaint of weight gain was present for many years and it was considered to be related with dysfunctional gastric band and dropped-out follow-ups. It has been criticized that the diagnosis has been made earlier if complaints had been carefully examined and additional tests such as abdominal tomography or gastroscopy had been performed during preoperative period.

AGB can be performed as open or laparoscopic surgery. Although open surgery was chosen in this patient, the more acceptable method is now minimally invasive surgery which has been increasingly used during the last decades. Two major surgical techniques, such as perigastric and pars flaccida, have been used in LAGB. Various complications, especially slippage and perforation have been more frequently reported in patients treated using the perigastric approach whose dissection is closer to the stomach. A significant decrease in complication rates has been observed with the pars flaccida technique which was defined later $(5,9,21)$. Although general practice is tended to choose the pars flaccida technique, there are also other 
practices which predominantly favour perigastric approach owing to its successful outcomes $(10,11)$. There was no information related with which method the first operation had been performed on this patient.

Keeping in mind the possibility of the IGBM in patients with the history of gastric banding is the most crucial part of diagnosis. First diagnostic modality must be upper GIS endoscopy and diagnosis can be made with endoscopic examination without any other imaging modality in many cases (5). Ultrasonography and computed tomography are more beneficial in patients with predominant non-specific symptoms (5). It may be suggested that performing preoperative endoscopic or radiological examination in patients scheduled for band removal may reduce the risk of unexpected intraoperative conditions as happened in the presented cases; and be more reasonable approach. The criticism in the present case is that avoidance of preoperative gastroscopy resulted in a long duration of the surgical intervention because of intraoperative endoscopy. Moreover; if we could not have seen the band during intraoperative gastroscopy because of a possible totally intramural location, we would not finish the operation with success.

Question of how surgeon should approach after IGBM diagnosis is made involves many different treatment algorithms. Although there are no ideal answers for questions like when or which methods, the treatment is removal of the band (3). There are groups suggesting immediate removal of the band right after identifying migration due to possibility of peritonitis and abscess in IGBM cases, however, there are also substantial amount of practices preferring elective operation after close monitoring $(3,11,19)$. The less invasive method is gastroscopic removal of the band and there are special devices developed for this purpose (gastric band cutter) $(9,11,19,20)$. In gastroscopic method which can even be performed under sedation, presence of arch of the gastric band in the stomach is important for utilization of the method. Laparoscopic surgery may also be added when endoscopy is not adequate alone (20).

Although gastroscopic method is less invasive, long hospitalization period, frequent gastroscopy need and high cost of this method have made laparoscopy the most preferred method $(3,12)$. In the laparoscopic method, a little gastrotomy incision is usually required for easier removal of the band, and repair of this created gastrotomy defect with an omental patch or primary closure are recommended $(12,13)$. However, there are cases in which the gastric bands were removed without gastrotomy according to migration level of the band. Open surgery is the alternative approach when laparoscopic removal is not possible. A classification according to the amount of migration guides us to choose which removal method to use (3). In this classification, gastroscopic approach is recommended in cases of migration of most of the band whereas laparoscopic approach or gastroscopic approach is recommended in cases with little migration of the band after close monitoring until progression to migration. Additional techniques may be required for the treatment of obesity after band removal. Consensus between the patient and the doctor on whether surgery will be performed in same operation or in different session is the most accurate approach $(5,8)$. In our case, open surgery was preferred due to planned incisional hernia repair and scar revision; and no additional intervention was performed due to the patient's refusal of bariatric procedures.

IGBM is a rarely seen complication after gastric banding surgery. It should be kept in mind that the band may migrate into the stomach in patients with a history of gastric banding and, in case of suspicion, the diagnosis should be confirmed with upper endoscopy, then endoscopic or surgical removal should be considered.

\section{Authorship Contributions}

Surgical and Medical Practices: M.U., R.Y., A.G. Concept: M.U, R.Y., K.T., M.S.B., S.T., S.T.A., A.G. Design: M.U., R.Y., K.T., M.S.B., S.T. Data Collection or Processing: M.U., R.Y., K.T., M.S.B., S.T., S.T. Analysis or Interpretation: M.U., R.Y., K.T., M.S.B., S.T., A.G. Literature Search: M.U., R.Y., K.T., S.T., S.T. Writing: M.U., A.G.

Conflict of Interest: No conflict of interest was declared by the authors.

Financial Disclosure: The authors declared that this study received no financial support.

\section{References}

1. Gagner M, Milone L, Yung E, Broseus A, Gumbs AA. Causes of early mortality after laparoscopic adjustable gastric banding. J Am Coll Surg 2008;206:664-9.

2. Allen JW. Laparoscopic gastric band complications. Med Clin North Am 2007;91:485-97.

3. Nocca D, Frering $V$, Gallix $B$, et al. Migration of adjustable gastric banding from a cohort study of 4236 patients. SurgEndosc 2005; 19:947-50.

4. Carelli AM, Youn HA, Kurian MS, Ren CJ, Fielding GA. Safety of the laparoscopic adjustable gastric band: 7-year data from a U.S. center of excellence. SurgEndosc 2010;24:1819-23.

5. Brown WA, Egberts KJ, Franke-Richard D, et al. Erosions after laparoscopic adjustable gastric banding: diagnosis and management. Ann Surg 2013;257:1047-52.

6. Mittermair RP, Aigner $F$, Obermuller $S$. Results and complications after Swedish adjustable gastric banding in older patients. Obes Surg 2008;18:1558-62. 
7. Cherian PT, Goussous G, Ashori F, Sigurdsson A. Band erosion after laparoscopic gastric banding: a retrospective analysis of 865 patients over 5 years. SurgEndosc 2010;24:2031-8.

8. Kurian M, Sultan S, Garg K, et al. Evaluating gastric erosion in band management: an algorithm for stratification of risk. SurgObesRelat Dis 2010;6:386-9.

9. Abu-Abeid S, Zohar DB, Sagie B, Klausner J. Treatment of intra-gastric band migration following laparoscopic banding: safety and feasibility of simultaneous laparoscopic band removal and replacement. Obes Surg 2005;15:849-52.

10. Belachew M, Belva PH, Desaive C. Long-term results of laparoscopic adjustable gastric banding for the treatment of morbid obesity. Obes Surg 2002;12:564-8.

11. Favretti F, Cadiére $G$, Segato $G$, et al. Laparoscopic banding: selection and technique in 830 patients. ObesSurg 2002;12:385-90.

12. Abu-Abeid S, Keidar A, Gavert N, Blanc A, Szold A. The clinical spectrum of band erosion following laparoscopic adjustable silicone gastric banding for morbid obesity. SurgEndosc 2003;17:861-3.

13. Kohn GP, Hansen CA, Gilhome RW, et al. Laparoscopic management of gastric band erosions: a 10-year series of 49 cases. SurgEndosc 2012;26:541-5.
14. Hussain AA, Nicholls J, El-Hasani SS. Laparoscopic adjustable gastric band: how to reduce the early morbidity. JSLS 2014;18. pii: e2014.00241.

15. Watkins BM, Ahroni JH, Michaelson R, et al. Laparoscopic adjustable gastric banding in an ambulatory surgery center. SurgObesRelat Dis 2008;4(Suppl):56-62.

16. Angrisani L, Furbetta F, Doldi, SB, et al. Lap Band $(\AA$ adjustable gastric banding system. SurgEndosc 2003;17:409-12.

17. Fried M, Miller K, Kormanova K. Literature review of comparative studies of complications with Swedish band and Lap-band. ObesSurg 2004;14:256-65.

18. Egbeare DM, Myers AF, Lawrance RJ. Small bowel obstruction secondary to intragastric erosion and migration of a gastric band. J GastrointestSurg 2007;17:983-4.

19. Neto MPG, Ramos AC, Campos JM, et al. Endoscopic removal of eroded adjustable gastric band: lessons learned after 5 years and 78 cases. SurgObesRel Dis 2010;6:423-8.

20. Aarts EO, van Wageningen $B$, Berends $F$, et al. Intragastric band erosion: experiences with gastrointestinal endoscopic removal. World J Gastroenterol 2015;21:1567-72.

21. Fielding GA, Allen JW. A step-by-step guide to placement of the LAP-BAND adjustable gastric banding system. Am J Surg 2002;184:26-30. 